\title{
KAJETAN HAMERLAK
}

Katolicki Uniwersytet Lubelski ORCID: 0000-0001-8967-8851 khamerlak@onet.eu

\section{SABINA BOBER}

Katolicki Uniwersytet Lubelski ORCID: 0000-0002-8857-4062 sabinabober@interia.pl

\section{NIEMIECKA REPUBLIKA FEDERALNA JAKO AZYL DLA NAZISTOWSKICH ZBRODNIARZY WOJENNYCH. ANALIZA WYBRANYCH ASPEKTÓW ŚCIGANIA I SKUTECZNOŚCI KARANIA}

\section{The German Federal Republic As an Asylum for Nazi War Criminals: The Analysis of Selected Aspects of Prosecution and Punishment Effectiveness}

West Germany had to come to terms with its wartime past in order to function on the international arena. This topic was also widely commented on in Polish press. Poland, which was one of the countries most affected by the extermination policy of Nazi Germany, was inevitably interested in holding the Nazis accountable for their crimes. Moreover, the authorities of the People's Republic of Poland wanted German crimes to be exposed all the time. In this way, the topic of Soviet crimes was avoided. Hence, the theme of punishment for Nazi war crimes was often discussed in the press. Many articles emphasised the pathological system of prosecuting the Nazis in West Germany, pointing to the post-war careers of the war criminals. Reluctance to face the past, exhibited primarily by the older generation, was also emphasised. The young generation of Germans, untouched by the war past, was to strive for moral renewal. It should be stressed that the post-war trials concerned only a small number of actual criminals, and the penalties were often disproportionate to the crimes committed. 


\section{WSTEP}

Analizowany w artykule sześcioletni okres rozpoczyna skandal na scenie politycznej NRF $z$ udziałem Theodora Oberländera - ministra federalnego ds. uciekinierów, wypędzonych i poszkodowanych przez wojnę - mający miejsce w latach 1959-1960, a kończy finał II procesu oświęcimskiego (lata 1963-1965), podczas którego zasądzono kary dla 22 byłych członków załogi tego obozu. Jest to okres niezwykle zasobny w różnego rodzaju próby rozliczenia nazistowskiej przeszłości $\mathrm{w}$ NRF, a także $\mathrm{w}$ polityczne skandale $\mathrm{z}$ udziałem dawnych funkcjonariuszy hitlerowskich. Swoiste nazistowskie „złogi” pozostałe w mentalności obywateli oraz polityków NRF wpłynęły niestety ujemnie na próby ukarania nazistowskich zbrodniarzy wojennych. Kary niewspółmierne niskie w stosunku do zarzucanych zbrodni oraz próby „ukrycia” członków nazistowskiego reżimu we władzach NRF spotkały się z krytyczna reakcja polskiej prasy, która w okresie rządów Władysława Gomułki (1956-1970) szczególnie zwracała uwagę na powiązania NRF $z$ nazistowską Rzesza, pomijając udział części elit politycznych, wojskowych i aparatu bezpieczeństwa Niemiec Wschodnich w zbrodniczym dziele Hitlera ${ }^{1}$.

Podstawą źródłową niniejszego tekstu sa artykuły zamieszczone na łamach prasy polskiej w latach 1959-1965. Wykorzystane zostały do tego celu następujace tygodniki: kulturalno-społeczny „Przekrój” oraz poświęcona tematyce warszawskiej „Stolica”. Materiału źródłowego dostarczyła ponadto "Trybuna Robotnicza” - dziennik PZPR wydawany przez Robotniczą Spółdzielnię Wydawnicza „Prasa”, a kolportowany na terenie województwa katowickiego, bielskiego oraz częstochowskiego ${ }^{2}$.

W okresie rządów Władysława Gomułki NRF stała się obiektem zmasowanej akcji propagandowej polskiej prasy, która miała $z$ tego państwa uczynić sojusznika byłych nazistów, nieskorego do karania zbrodni hitlerowskich. Wśród licznych oskarżeń znalazły się

\footnotetext{
1 W publicznej narracji całkowicie wykluczano wszelkie watki nawiąujące do narodowosocjalistycznej przeszłości m.in. części funkcjonariuszy Ministerstwa Bezpieczeństwa Państwowego NRD (Ministerium für Staatsicherheit), np. Rudolfa Bamlera - w okresie wojennym piastującego wysokie stanowisko w Abwehrze. Szerzej problematykę udziału dawnych narodowych socjalistów w tworzeniu zrębów państwowości NRD porusza R. Wiedmann, Die Diensteinheiten des MfS 1950-1989. Eine organisatorische Übersicht, Der Bundesbeauftragte für die Unterlagen des Staatssicherheitsdienstes der ehemaligen Deutschen Demokratischen Republik, Berlin 2012.

2 A. Słomkowska, Prasa $w$ PRL. Szkice historyczne, Państwowe Wydawnictwo Naukowe, Warszawa 1980, s. 330.
} 
m.in. zarzuty udzielania azylu zbrodniarzom wojennym, a także ciche zezwolenie na ich udział w życiu publicznym $\mathrm{NRF}^{3}$. Poglady te były szeroko rozpowszechniane oraz komentowane w prasie polskiej oraz naukowym piśmiennictwie dotyczacym zagadnień politycznych, socjologicznych, społecznych, prawnych oraz historycznych państwa zachodnioniemieckiego. Tytuły takie, jak: Heimatrecht a społeczna rzeczywistośc; Militaryzm niemiecki; Neohitleryzm. Ideologia, propaganda, formy działania $i$ warunki rozwoju ruchu neohitlerowskiego; Ostpolitik a samostanowienie narodów, jednoznacznie wskazywały na NRF jako spadkobiercę imperializmu III Rzeszy ${ }^{4}$.

Stanowisko przyjmowane przez autorów tekstów prasowych, publicystycznych oraz naukowych stanowiło odzwierciedlenie dyrektyw Wydziału Propagandy i Agitacji KC PZPR. Realizowano także wytyczne Biura Prasy KC PZPR (struktura funkcjonujaca w latach 1956-1972) $)^{5}$. Szczególnym zainteresowaniem propagandystów PZPR (oprócz opieszałości wymiaru sprawiedliwości NRF wobec dawnych narodowych socjalistów) cieszył się także problem zachodnioniemieckiego „rewizjonizmu”. Problem roszczeń terytorialnych NRF względem PRL (kwestionowanie przyznania Polsce tzw. Ziem Odzyskanych) nagminnie łączono $z$ nazistowska przeszłością części zachodnioniemieckich polityków, którzy w okresie powojennym publicznie wspierali organizacje ziomkowskie lub partie polityczne $z$ nimi powiazane (np. Blok Wszechniemiecki). Wytyczne nadajace kierunek narracji propagandowej w kwestii NRF obecne sa także w przemówieniach czołowych polityków oraz działaczy PZPR i organizacji od niej zależnych. Za przykład może posłużyć referat wygłoszony 5 kwietnia 1961 roku przez ministra spraw zagranicznych Adama Rapackiego pt. „W walce

3 Problematyka związana $\mathrm{z}$ mankamentami zachodnioniemieckich procesów karnych zbrodniarzy narodowosocjalistycznych wiąże się ściśle $z$ pozostałościami amerykańskich, brytyjskich i francuskich norm prawnych regulujacych tę sferę (szereg sprzeczności natury prawnej rodziły niezgodności przepisów NRF z wytycznymi Sojuszniczej Rady Kontroli) jeszcze w pierwszych latach istnienia NRF (aż do 1951 r.). Zob. A. Eichmüller, Keine Generalamnestie. Die Strafverfolgung von NS-Verbrechen in der frühen Bundesrepublik, De Gruyter Oldenbourg, München 2012, s. 53.

${ }_{4}$ Więcej na ten temat zob. R. Bierzanek, A. Czakowski, J. Lubojański, K. Żygulski, Heimatrecht a społeczna rzeczywistość, Wydawnictwo ZAP, Poznań 1962; A.J. Kamiński, Militaryzm niemiecki, Wydawnictwo ZAP, Poznań 1962; A.J. Kamiński, Neohitleryzm. Ideologia, propaganda, formy działania i warunki rozwoju ruchu neohitlerowskiego, Wydawnictwo Poznańskie, Poznań 1962; A. Leśniewski, Ostpolitik a samostanowienie narodów, Wydawnictwo ZAP, Warszawa-Poznań 1963; K. Kakol, Zbrodnia nie ukarana. Ściganie zbrodniarzy hitlerowskich $w$ NRF (1959-1969), Wydawnictwo „Książka i Wiedza”, Warszawa 1970, s. $171-173$.

5 Ł. Kamiński, Struktury propagandy $w$ PRL w: Propaganda PRL, red. P. Semkow, Instytut Pamięci Narodowej - Komisja Ścigania Zbrodni przeciwko Narodowi Polskiemu, Gdańsk 2004, s. 11. 
z rewizjonizmem zachodnioniemieckim". W swoim przemówieniu polityk zaznaczył, iż problem występujących w Niemczech Zachodnich postaw rewizjonistycznych swoimi korzeniami sięga lat istnienia III Rzeszy, a nawet okresów wcześniejszych: feudalnego oraz pruskiego $^{6}$. Identyczna linię argumentacyjna przyją tow. Sobczak w swoim przemówieniu wygłoszonym na konferencji Towarzystwa Rozwoju Ziem Zachodnich, która miała miejsce 29-30 września 1966 roku. Tezy postawione przez Sobczaka zupełnie otwarcie łączyły organizacje ziomkowskie NRF $z$ organizacjami mniejszości niemieckiej w II RP - ugrupowaniami niejednokrotnie silnie powiazanymi $z$ narodowymi socjalistami ${ }^{7}$. Zaprezentowane powyżej przykłady jasno obrazują linię propagandowa przyjęta przez KC PZPR w kwestii Niemiec Zachodnich. Stanowiła ona podstawowy wyznacznik interpretacji wydarzeń zachodzących w NRF, który obowiązywał prasę Polskiej Rzeczypospolitej Ludowej w okresie rządów Władysława Gomułki.

\section{BYLI NAZIŚCI PRZED WYMIAREM SPRAWIEDLIWOŚCI I WE WŁADZACH NRF}

Zachodnioniemieckie podejście do problemu karania zbrodniarzy wojennych stało się na łamach polskiej prasy zjawiskiem szeroko komentowanym. Powszechnie stosowanym oskarżeniem $\mathrm{w}$ tej kwestii stała się zbytnia pobłażliwość dla zbrodniarzy wojennych ze strony wymiaru sprawiedliwości NRF. Nieprawidłowości w tym zakresie prasa polska rozpatrywała dwuaspektowo: ukazywano zbrodnie popełnione przez sądzonych oraz niewspółmiernie niską za nie karę. Można tu przedstawić przypadek Karla Wolffa, byłego adiutanta oraz szefa sztabu Heinricha Himmlera, a także wyższego dowódce SS i policji we Włoszech. W zamieszczonym przez tygodnik „Stolica” artykule zaprezentowano oskarżenia o jego udział m.in. w organizacji transportów ludności żydowskiej do Treblinki oraz opracowywaniu planów niemieckiej kolonizacji Ukrainy. Na uwagę zasłużyło dosłowne zacytowanie przez autora tekstu, motywu niskiej kary dla zbrodniarza. W 1949 roku sąd w Hamburgu skazał Wolffa na 4 lata więzienia, z których były nazista odsiedział 7 dni - „Wolff, czysty w swej istocie

\footnotetext{
${ }^{6}$ Archiwum Akt Nowych w Warszawie, Komitet Centralny PZPR, sygn. 237/VIII/ 1085, Referat Tow. Adama Rapackiego pt. „W walce $\mathrm{z}$ rewizjonizmem zachodnioniemieckim”, k. 2-27

7 AAN, KC PZPR, sygn. 237/ VIII/872, Przemówienie tow. Sobczaka na konferencji nt. działalności organizacji rewizjonistycznych w Niemczech, 29-30 września 1966, k. 6-24.
} 


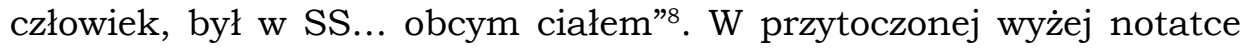
znalazły się wszystkie elementy mające wzbudzić odrazę zarówno wobec oskarżonego, jak i wymiaru sprawiedliwości, który uniewinnił takiego mordercę.

Dokładną kopię powyższego schematu można zaobserwować ponadto w sprawozdaniu dotyczącym procesu dwóch współpracowników Adolfa Eichmanna - Hermana Krumeya (były pełnomocnik Eichmanna na Węgrzech) oraz Ottona Hunschego (były łącznik pomiędzy dowództwem SS a władzami węgierskimi), których sądzono we Frankfurcie nad Menem (lata 1964-1965) za współudział w zagładzie 300 tys. węgierskich Żydów. W notatce prasowej „Trybuny Robotniczej” wyraźnie zarysowano kontrast pomiędzy skala zbrodni a karygodnie wręcz niskimi wyrokami dla byłych nazistów (5 lat więzienia dla Krumeya oraz uniewinnienie Hunschego). Fragment notatki opisujący uzasadnienie wyroku, skonstruowano tak, aby przedstawić system prawny NRF jako sprzyjający zbrodniarzom narodowosocjalistycznym:

Znamienne były tezy uzasadnienia wyroku. Przynależność do „Sonderkommando Eichmanna" - jak stwierdził sąd - nie jest dowodem winy obu oskarżonych. Skazanie mogłoby nastapić wtedy, gdyby udowodniono bez reszty winę każdego oskarżonego'.

Problemem niezwykle obszernie poruszanym na lamach prasy polskiej stały się zagadnienia dotyczące byłych funkcjonariuszy narodowosocjalistycznych, którym w okresie powojennym umożliwiono robienie karier politycznych oraz wojskowych. $Z$ racji obszerności zagadnienia $\mathrm{w}$ tekście tym zostana poruszone tylko najbardziej reprezentatywne przypadki.

Szeroko komentowana w prasie stała się sprawa Theodora Oberländera. Ten niegdysiejszy hitlerowski urzędnik, pracownik naukowy i wywiadowca specjalizujący się $\mathrm{w}$ sprawach wschodnioeuropejskich, w Niemieckiej Republice Federalnej pełnił wiele odpowiedzialnych

8 J. Zarański, Portrety brunatnej galerii. Wilk $w$ owczej skórze. Bawarska idylla adiutanta Himmlera, „Stolica” 1962, nr 13, s. 14. Warto nadmienić, iż Wolff cieszył się szczególnymi względami ze strony amerykańskich służb specjalnych. Zjawisko to wynikało głównie $z$ proamerykańskiej postawy esesmana, która ten reprezentował podczas negocjacji $z$ szefem OSS w Europie Allanem Dullesem pomiędzy lutym a majem 1945 r. (Operacja „Wschód Słońca”). Negocjacje dotyczyły warunków kapitulacji sił niemieckich we Włoszech. Szerzej: zob. K. von Lingen, Der lange Weg zum Verhandlungsfriend. Hintergründe und Interessen an „Operation Sunrise”, w: Für Freiheit und Recht in Europa. Der 20. Juli und der Widenstand gegen das NS-Regime in Deutchland, Österreich und Südtirol, red. G. Steinacher, H-G. Richardi, Studien Verlag, Innsbruck 2009, s. 174-206.

9 Oburzajacy wyrok na pomocników Eichmanna. 5 lat więzienia $i$ uniewinnienie za współudział w morderstwie 300 tys. Żydów, „Trybuna Robotnicza” 1965, nr 29, s. 2. 
funkcji. Powierzono mu stanowisko m.in. ministra federalnego ds. wypędzonych, uciekinierów i poszkodowanych przez wojnę w rządzie Konrada Adenauera, sekretarza stanu ds. przesiedleńców w rządzie landu Bawaria, deputowanego do Bundestagu oraz landtagu Bawarii, a także współpracownika wielu partii politycznych (m.in. FDP, CDU, BHE) i organizacji pozarzadowych (m.in. Ruchu Odrodzenia Moralnego ${ }^{10}$.

$\mathrm{Na}$ łamach polskiej prasy sylwetkę Oberländera odmalowano w charakterystyczny sposób, skupiając się na uwypukleniu zbrodni byłego nazisty, ukazaniu jego zaangażowania w nazistowska politykę eksterminacyjną, a także nieudolne próby wybielenia własnej przeszłości. Zgodnie $z$ relacjami prasowymi pełnił on funkcje oficera politycznego batalionu „Nachtigall”, oficera Abwehry przy dowództwie 8. Okręgu Wehrmachtu we Wrocławiu - specjalisty do spraw „wschodnich", a także Hauptsturmführera SA ${ }^{11}$. Do NSDAP Oberländer wstapił w 1934 roku. Mieczysław Kieta scharakteryzował go jako „wybitnego działacza reżimu hitlerowskiego i przewodniczącego organizacji Prus Wschodnich"12. Władysław Bartoszewski - autor cyklu zwrócił ponadto uwage na „naukowe” predyspozycje przyszłego ministra, które świadczyły o przydatności do służby w oddziałach dywersyjnych Abwehry - m.in. studia ekonomiczno-rolnicze w Hamburgu i Berlinie (1927-1929), dwuletnią (1930-1932) podróż naukową po ZSRR, funkcje kierownicze w Związku Niemieckiego Wschodu (BDO) i Zrzeszeniu Niemców Zagranica (VDA) oraz posadę dyrektora Instytutu dla Spraw Europy Wschodniej (od 1936 r.) ${ }^{13}$. W opinii wymienionych dziennikarzy jednym $z$ najmroczniejszych okresów wojskowej służby Oberländera miała być jego działalność w batalionie „Nachtigall” (niem. słowik) w charakterze zwierzchnika politycznego, który wchodził w skład dywersyjnego pułku „Brandenburg”

[...] batalion, przeznaczony do zadań politycznych i wojskowych specyficznego pokroju. Batalion ten, składający się $z$ około 600 Ukraińców pod dowództwem 60 niemieckich podoficerów oraz hitlerowskich oficerów $[\ldots]^{14}$.

10 A. Drożdżyński, J. Zborowski, Oberländer. Przez „Ostforschung” wywiad i NSDAP do rządu NRF, Wydawnictwo Zachodnie, Poznań-Warszawa 1960, s. 152-154.

11 Szerzej wojenna przeszłość Oberländera przedstawiaja następujące publikacje: S. Schütt, Theodor Oberländer: eine dokumentarische Untersuchung: mit 61 Abbildulgen und Dokumenten, Langen Müller, München 1995 oraz P.C. Wachs Der Fall Theodor Oberländer (1905-1998): Ein Lehrstück deutscher Geschichte, Campus Verlag, Frankfurt/Main 2000. M. Kieta, Słowik z Bonn czyli rzecz o ministrze Oberlaenderze, „Przekrój” 1960, nr 770, s. 4.

12 Ibidem.

13 W. Bartoszewski, Oberländer jakiego znamy, „Stolica” 1960, nr 15, s. 6.

14 M. Kieta, Słowik z Bonn..., s. 4; W. Bartoszewski, Oberländer jakiego znamy, s. 7. 
Niezwykle obszerne dowody winy zamieszczono w tygodniku „Stolica”. Ich autor - Władysław Bartoszewski w zbiorczym cyklu o tytule Oberländer jakiego znamy zaprezentował szereg relacji świadków historii oraz dokumentów poświadczających udział przyszłego ministra oraz jego ukrainskich podkomendnych w zbrodniach wojennych, zwłaszcza w egzekucjach polskiej inteligencji Lwowa w lipcu 1941 roku. W relacjach nie brak elementów "charakterystycznych”, takich jak szczegółowe przedstawienie przebiegu egzekucji, rabunku mienia ofiar, brutalnych przesłuchań oraz świadków rozpoznających morderców. W swych tekstach autor oparł się przede wszystkim na zeznaniach naocznych świadków. Za przykład może posłużyć relacja Heleny Kucharowej, która rozpoznała byłego oficera Abwehry w gronie żołnierzy dokonujących egzekucji:

Spoglądał na mnie długo, $z$ uwaga, $z$ zaciekawieniem. Jego spojrzenie nie było surowe w tym sensie, żeby wyrażało oburzenie. Nie było to spojrzenie karcace, ale wyrażające tak jakby zainteresowanie moim wyrazem twarzy i jakby zastanowienie, czy mogłam widzieć egzekucję.

Wywód świadka w oczywisty sposób kontrastuje z zapewnieniami Oberländera o niewinności: „w ciagu sześciu dni pobytu "Nachtigall» we Lwowie nie padł ani jeden strzał" ${ }^{15}$.

Jak pisze Mieczysław Kieta, Oberländer nie ukrywał swojej nazistowskiej przeszłości, jednak w sposób zdecydowany odpierał oskarżenia o udział w egzekucjach lwowskiej inteligencji. W zarejestrowanej w stolicy Niemiec Zachodnich wypowiedzi (rok 1958) stwierdził ponadto, iż „Wkroczenie do Lwowa sprawiło mi uczucie prawdziwego szczęścia..." ${ }^{16}$. Sprawa Oberländera doprowadziła do politycznego blamażu NRF. Dodatkowym obciążeniem dla wpływowego protektora Oberländera - kanclerza Konrada Adenauera - stały się nieprzemyślane wypowiedzi ministra ds. przesiedleńców. W otwarty sposób przyznał się on do udzielania wsparcia byłym nazistom pracującym $\mathrm{w}$ jego resorcie (mieli oni stanowić aż 86 proc. personelu) ${ }^{17}$. Sprawa ta ponownie zagościła w polskiej prasie w grudniu 1959 roku. Problem przeszłości ministra omawiano w związku $z$ powołaniem w NRF specjalnej komisji mającej zbadać tę sprawę. Zeznania złożone przed wspomnianą komisja przez niegdysiejszego oficera Abwehry stały się

15 W. Bartoszewski, Oberländer-jakiego znamy, s. 19.

16 M. Kieta, Słowik z Bonn..., s. 4.

17 W resorcie Oberländera zatrudnienie znaleźli m.in. były oficer SS dr Erich Wolfram oraz Werner Ventzki - były burmistrz Łodzi oraz członek NSDAP. T.H. Tetens, Naziści znowu u władzy, tłum. B. Norton, Wydawnictwo „Książka i Wiedza”, Warszawa 1963, s. 77. 
asumptem do krytyki na łamach prasy nie tylko samego ministra federalnego, ale także kanclerza Adenauera. Zarzucono mu, iż zaklinając się na demokrację, zatrudnia na ministerialnym stanowisku „byłego oficera politycznego batalionu "Nachtigal" do specjalnych zadań eksterminacyjnych"18. Prace komisji weryfikującej przeszłość byłego członka SA stały się znacznym obciążeniem dla rządu NRF, a w efekcie doprowadziły do rozłamu w samej komisji, która nie była w stanie dokonać pozytywnej weryfikacji przeszłości Oberländera ${ }^{19}$. Opuścił on zachodnioniemiecka scenę polityczną 4 maja 1960 roku, zdając dotychczas pełniony urząd. Na decyzję władz zachodnioniemieckich wpływ miały także naciski ze strony NRD, która obarczała ministra dodatkowo odpowiedzialnościa za prześladowania działaczy komunistycznych $^{20}$. Jego następca mianowano Hansa von Merkatza (także byłego członka NSDAP w latach 1933-1945).

Osoba Theodora Oberländera to nie jedyny przypadek byłego funkcjonariusza państwa nazistowskiego, któremu w Niemczech Zachodnich ułatwiono karierę polityczna. Na łamach prasy polskiej równie często jak o politykach $z$ narodowosocjalistyczna przeszłościa pisano o zawodowych oficerach Bundeswehry, których życiorysy „skalała” służba w Wehrmachcie. Zabieg ten niezwykle często łączono $z$ dokumentalnym przedstawieniem zbrodni wspomnianych osób, które w zamierzeniu dziennikarzy ukazywać miały rzeczywiste oblicze armii NRF, a zwłaszcza jej zbytnią tolerancję dla osób odpowiedzialnych za zbrodnie wojenne (powoływano się $z$ reguły na te popełnione w Polsce):

Ludzie, którzy przed dwudziestu trzema laty krwawo i jakże często zbrodniczo zapisali się nad Wisła, dzisiaj dowodzą nową armią niemiecką nad Renem ${ }^{21}$.

Jednym $z$ najszerzej krytykowanych dowódców Bundeswehry stał się gen. Heinrich Trettner. Zachodnioniemiecki oficer - jeden $z$ wyższych dowódców 7. Dywizji Lotniczej w okresie II wojny światowej

18 Sprawa Oberländera, „Przekrój” 1959, nr 765, s. 2.

19 Oberländer, „Przekrój” 1960, nr 785, s. 2; Sprawę nazistowskiej przeszłości Oberländera rozpatrywano również w Niemczech Wschodnich. W dniach 20-29 kwietnia 1960 r. toczył się przeciw niemu proces przed Sąem Najwyższym NRD. Minister ds. przesiedleńców został oskarżony m.in. o udział w egzekucjach lwowskiej inteligencji oraz organizację działań dywersyjnych na froncie wschodnim. Został on zaocznie skazany na karę dożywotniego więzienia. N.S. Aleksiejew, Odpowiedzialność przestępców hitlerowskich, tłum. W. Bielawski, Ministerstwo Sprawiedliwości - Główna Komisja Badania Zbrodni Hitlerowskich w Polsce, Warszawa 1969, s. 49-50.

20 D. Schenk, Der Lemberger Professorenmord und der Holocaust in Ostgalizien, Dietz Verlag, Bonn 2007, s. 255.

${ }_{21}$ L. Moczulski, Portrety brunatnej galerii. Wrzesien i dowódcy Bundeswehry, „Stolica” 1962, nr 35, s. 14. 
- w NRF piastował stanowisko zwierzchnika 1 korpusu armijnego Bundeswehry. W standardowej narracji polskiej prasy zarzucono mu udział $\mathrm{w}$ zbrodniach $\mathrm{z}$ okresu wojennego. Dawna jednostkę Trettnera opisano jako grupę przeznaczona do działań dywersyjnych na tyłach frontu (stosowali m.in. mundury przeciwnika). Do listy przestępstw wojennych dodano także rozkaz bombardowania Rotterdamu z 14 maja 1940 roku, który Trettner miał wydać już po kapitulacji miasta ${ }^{22}$. W narracji dziennikarskiej pojawiały się ponadto niedwuznaczne oskarżenia wobec zachodnioniemieckiego rządu, którego niechęć do usunięcia zbrodniarza $z$ armii odbierano jako przejaw ochrony państwa dla byłych nazistów zajmujących ważne stanowiska państwowe:

Rada Narodowa podkreśla, że oświadczenie ministra obrony NRF von Hassela z 13 kwietnia, w którym zajał on stanowisko wobec zarzutów stawianych Trettnerowi, mimo prób wybielania go stanowi faktyczne potwierdzenie tych zarzutów ${ }^{23}$.

Jako „oczywistego” inicjatora usunięcia Trettnera ukazano niemieckie środowiska "postępowe”, ich postulaty znajdowały odzwierciedlenie w działaniu Komunistycznej Partii Niemiec, która jako jedyne ugrupowanie polityczne NRF pragnęła (w sojuszu $z$ SPD) poddać sprawę pod głosowanie na forum Bundestagu ${ }^{24}$.

Problem niewłaściwego obsadzenia federalnego ministerstwa ds. wypędzonych, uciekinierów i poszkodowanych przez wojnę nie dotyczył wyłącznie osoby Oberländera („obsadzenie ministerstwa do spraw przesiedleńców stoi w Bonn pod "Szczególnie zła gwiazdą")" ${ }^{25}$. Nazistowska przeszłość jednego $z$ jego następców - Hansa Krügera doprowadziła do skandalu politycznego w NRF w latach 1963-1965. W tym przypadku osobę ministra pograżyła jego działalność w hitlerowskim wymiarze sprawiedliwości, a w szczególności funkcja przewodniczacego sadu specjalnego w Chojnicach w latach 1939-1943. W okresie okupacji służył on ponadto w SA, a także piastował stanowisko Ortsgruppenleitera NSDAP w Chojnicach ${ }^{26}$. Fakt ten stanowił

22 Ibidem. Pomimo podpisania aktu kapitulacji Trettner zarzadził zniszczenie Rotterda$m u$, „Trybuna Robotnicza” 1964, nr 62, s. 2.

${ }_{23}$ Oświadczenie Rady Narodowej Frontu Narodowego Niemiec Demokratycznych: Usunać przestępce wojennego generała Trettnera, „Trybuna Robotnicza” 1964, nr 90, s. 2.

${ }^{24}$ KPD domaga się zbadania przeszłości Trettnera, „Trybuna Robotnicza” 1964, nr 60, s. 2.

25 Pod naporem ujawnionych $w$ Polsce $i$ NRD faktów. Krueger zawieszony $w$ czynnościach ministra rzadu bońskiego, „Trybuna Robotnicza” 1964, nr 19, s. 1.

${ }^{26} \mathrm{http} / / /$ www.historiachojnic.pl/artykuly/materialy/II-wojna-swiatowa/51/chojnickim-sladem-dr-krugera [dostęp: 17 czerwca 2020]. 
dla polskiej prasy okazję do ujawnienia niekompetencji zachodnioniemieckiego rządu, zwłaszcza w kwestiach dotyczacych karania zbrodniarzy wojennych, a także usuwania ich $z$ eksponowanych stanowisk. Zarzuty wysunięto wobec Krügera, którego oskarżano o tuszowanie własnej przeszłości i wybielanie zbrodni:

[...] nie może sobie przypomnieć, czy brał udział $\mathrm{w}$ wydawaniu wyroków śmierci, gdyż czyniono to przecież w sposób „czysto rutyniarski”. Jak mogę przeszkodzić temu, że pewnego dnia okaże się, iż współdziałałem w wydawaniu wyroków śmierci?

Krytyce poddano także partyjnych kolegów Krügera z CDU ${ }^{27}$. Mięli oni mianowicie wskazywać na uczciwość byłego lidera NSDAP w Chojnicach, który po ujawnieniu nazistowskiej przeszłości sam poprosił kanclerza Ludwiga Erharda o usunięcie $z$ urzędu:

Frakcja parlamentarna CDU/CSU, $z$ której szeregów wywodzi się Krueger, nie omieszkała wskazać na „uczciwa postawę” Kruegera, jako że rzekomo sam prosił o zawieszenie w czynnościach ${ }^{28}$.

W sprawę Krügera zaangażowano stronę polska, która poprzez Prokuraturę Generalną PRL oraz Główna Komisję Badania Zbrodni Hitlerowskich w Polsce przekazały NRF dokumentację zbrodni ministra w naszym kraju ${ }^{29}$. Po usunięciu ministra ze stanowiska w roku 1964 jego zbrodnie popełnione w okresie wojennym nie stały się przedmiotem dochodzenia. Zachodnioniemiecka prokuratura nie znalazła żadnych dowodów winy Krügera ${ }^{30}$

\section{PROCES OŚWIĘCIMSKI (1963-1965)}

Jednym z przełomowych wydarzeń dotyczacych problemu rozliczenia się $z$ hitlerowska przeszłością w NRF był przeprowadzony w latach 1963-1965 tzw. II proces oświęcimski (w prasie polskiej określany

27 Boński minister bezradny wobec dowodów winy, „Trybuna Robotnicza” 1964, nr 18, s. 2 .

28 Pod naporem ujawnionych $w$ Polsce $i$ NRD faktów..., s. 1.

29 Główna Komisja Badania Zbrodni Hitlerowskich w Polsce była jednym $z$ głównych podmiotów odpowiadających za ściganie zbrodni hitlerowskich. Powołana w marcu 1945 r. przez PKWN komisja odpowiadała m.in. za zbieranie dowodów zbrodni nazistowskich w Polsce oraz ekstradycję przestępców hitlerowskich. Szerzej: zob. M. Roth, Herrenmenschen. Die deutsche Kreishauptleute im besetzen Polen - Karrierewege, Herrschaftspraxis und Nachgeschichte, Wallstein, Göttingen 2009, s. 314-317.

30 https://web.archive.org/web/20110303211720/http://www.braunbuch.de/6-02. shtml\#i02 [dostęp: 2 października 2020]. 
także mianem „procesu frankfurckiego) ${ }^{31}$. Jego głównym celem stało się wymierzenie sprawiedliwości członkom załogi obozu oświęcimskiego. Na łamach prasy polskiej do wydarzenia podchodzono w sposób dwojaki. $Z$ jednej strony w procesie widziano możliwość przeprowadzenia pierwszego poważniejszego rozliczenia $z$ nazistowska przeszłościa na terenie Republiki Federalnej ${ }^{32}$. Z drugiej natomiast obawiano się sprowadzenia rozprawy do kolejnego niewiele znaczacego wydarzenia, które będzie jedynie sprawiać wrażenie rozliczenia się $z$ nazistowskimi zbrodniami - zbrodniarze zostana uniewinnieni lub otrzymaja symboliczne wyroki.

Proces oświęcimski we Frankfurcie - nie łudźmy się - nie oznacza w NRF przewartościowania hitlerowskiej przeszłości, nie jest żadnym przełomem. Jest po prostu jednym procesem więcej, prowadzonym $z$ całą skrupulatnościa niemieckiej procedury karnej ${ }^{33}$.

Rozpoczęcie 20 grudnia 1963 roku we Frankfurcie nad Menem drugiego procesu, w którym na ławie oskarżonych zasiedli członkowie personelu obozu koncentracyjnego Auschwitz - Birkenau, przyjęto w Polsce ze zrozumiałym zainteresowaniem. Na łamach prasy pojawiło się wiele oskarżeń wobec sądownictwa w NRF. Domagano się wyjaśnień, dlaczego proces oświęcimskiej załogi rozpoczęto dopiero 18 lat po zakończeniu wojny oraz dlaczego w Niemieckiej Republice Federalnej

31 Proces załogi obozu oświęcimskiego $z$ lat 1963-1965 nie był jedynym procesem zbrodniarzy nazistowskich, jaki odbył się we Frankfurcie nad Menem. W latach 1949-1950 toczył się tam proces załogi obozu zagłady w Sobiborze. Szerzej: D. Knellessen, Transnarodowi świadkowie - żydowscy ocalali $w$ pierwszym procesie $w$ sprawie Sobiboru we Frankfurcie nad Menem i Berlinie Zachodnim, tłum. M. Koszutska, w: W cieniu Norymbergi. Transnarodowe ściganie zbrodni nazistowskich, red. R. Traba, K. Woniak, E. Heitzer, G. Morsch, Instytut Studiów Politycznych Polskiej Akademii Nauk, Centrum Badań Historycznych Polskiej Akademii Nauk w Berlinie, Warszawa-Berlin 2019, s. 261-276.

32 Do momentu rozpoczęcia procesu frankfurckiego temat zbrodni popełnionych w Oświęcimiu podejmowano jedynie w Norymberdze (m.in. w procesie koncernu IG Farben, w procesie Oswalda Pohla i Głównego Urzędu Gospodarki i Administracji SS oraz w procesie lekarzy SS), podczas procesu komendanta Auschwitz-Birkenau Rudolfa Hössa (Warszawa 1947), w tzw. pierwszym procesie oświęcimskim (Kraków i Wadowice 1947) oraz w szeregu procesów wytaczanych przez władze NRF poszczególnym członkom załogi obozu oświęcimskiego na przełomie lat pięćdziesiątych i sześćdziesiątych XX w. Tematykę procesów załóg obozów koncentracyjnych poruszono w sposób obszerny w anglo- oraz niemieckojęzycznej literaturze naukowej, m.in. w: J. Wilke, B. Schenk, A.A. Cohen: Holocaust und NS-Prozesse. Die Presseberichterstattung in Israel und Deutschland zwischen Aneignung und Abwehr, Böhlau, Köln 1995; A. Rückerl, Die Strafverfolgung von NS-Verbrechen 1945-1978. Eine Dokumentation, Juristischer Verlag Müller, Heidelberg-Karlsruhe 1979; D.O. Pendas, The Auschwitz Frankfurt Trial, 1963-1965. Genocide, History, and the Limits of the Law, Cambridge University Press, Cambridge 2006.

33 R. Wojna, Oprawcy z Oświęcimia przed sadem NRF. Zbrodnie jednostek czy systemu? „Trybuna Robotnicza” 1964, nr 6, s. 2. 
spokojnie żyła i mieszkała tak znaczna liczba zbrodniarzy wojennych. A także dlaczego nie poddano ich społecznemu ostracyzmowi $z$ racji dokonanych zbrodni. W tygodniku „Przekrój” wyrażono opinię, iż frankfurcka rozprawa być może zaktywizuje społeczeństwo wokół problemu fałszowania historii, a także zahamuje tendencje usprawiedliwiania zbrodniarzy ${ }^{34}$.

Na ławie oskarżonych zasiadło 24 byłych członków obozowego personelu. Spośród tego grona końca procesu doczekało $22^{35}$. Podczas wojny najwyższe stanowisko spośród postawionych przed sadem zbrodniarzy zajmował Robert Mulka (adiutant Rudolfa Hössa). Zarzuty usłyszało również pięciu pracowników obozowego gestapo (m.in. Wilhelm Boger, Hans Stark, Klaus Dybowski i Pery Broad), trzech lekarzy (dr Franz Bernhardt Lucas, dr Wilhelm Frank i dr Wilhelm Ludwig Schatz), farmaceuta obozowej apteki Viktor Capesius, pięciu sanitariuszy (m.in. Josef Klehr, Herbert Scherp, Emil Hantl i Gerhardt Neubert), komendant obozu Birkenau Stefan Baretzki, komendant obozu cygańskiego Franz Hofmann, szef raportów w Auschwitz Oswald Kaduk, dozorca „bloku śmierci” Bruno Schlage oraz więzień funkcyjny Emil Bednarek ${ }^{36}$.

Nakreślenie przebiegu „procesu frankfurckiego” na łamach polskiej prasy ma charakter wielopłaszczyznowy. W niezwykle szczegółowych tekstach (publikowano je w „Przekroju” oraz „Trybunie Robotniczej”) można wyodrębnić kilka warstw: postawy świadków i oskarżonych, działania prokuratorów i obrońców, sposób odbioru procesu w zachodnioniemieckim społeczeństwie, a także towarzysząca relacjom swoista „poświatę" ukazująca ogrom zbrodni oskarżonych oraz unaoczniająca patologie społeczeństwa, które nie chce rozliczyć się ze swoja przeszłościa.

Materiał dowodowy procesu we Frankfurcie nad Menem obejmował zeznania około 250 świadków, w tym kilkudziesięciu byłych więźniów Auschwitz-Birkenau, którzy po zakończeniu wojny zamieszkali poza granicami NRF, m.in. w Polsce, Czechosłowacji, NRD oraz Austrii ${ }^{37}$. Zeznania świadków - byłych więźniów oświęcimskich - stanowiły $\mathrm{w}$ materiałach przedstawianych przez polska prasę zupełna odwrotność relacji oskarżonych (próbowali oni obrazować swoją wo-

${ }^{34}$ Oświęcimski proces, „Przekrój” 1964, nr 980, s. 2.

35 Przed zakończeniem procesu zmarł oskarżony Richard Baer, natomiast zły stan zdrowia wykluczył z postępowania karnego Hansa Nierzwickiego. K. Kąkol, Zbrodnia nie ukarana..., s. 22-23.

${ }^{36}$ M. Kieta, Proces we Frankfurcie, „Przekrój” 1964, nr 985, s. 4-5.

37 K. Kakol, Zbrodnia nie ukarana..., s. 22. 
jenna przeszłość w najkorzystniejszy dla siebie sposób) ${ }^{38}$. Umiejętne operowanie cytatami, a także zamieszczanie w zeznaniach zwrotów niosacych ładunek emocjonalny stanowiło zabieg obliczony na przedstawienie dwóch obecnych na procesie biegunów. Pierwszy $z$ nich reprezentowali świadkowie - osoby opisujące wydarzenia w sposób niezafałszowany, kierujące się wyłącznie chęcią wymierzenia sprawiedliwości zbrodniarzom. Na drugim stanęli sądzeni - byli naziści, częstokroć kierujacy się oportunizmem, zasłaniajacy się lukami pamięci lub przerzucający odpowiedzialność na innych zbrodniarzy (w wielu przypadkach już nieżyjących), a także otwarcie zarzucający kłamstwo więźniom. W takiej konwencji utrzymano przebieg składania relacji przez świadka Ludwiga Wörla:

[...] przy zeznaniach odnośnie Kaduka spokój opuścił świadka. W lecie 1944 roku - mówi - przybył duży transport Żydów czeskich. Wraz z nimi dzieci. Kilkoro $\mathrm{z}$ nich udało mi się zachować przy życiu. W styczniu 1944 roku przybiegły do mnie płacząc, że Kaduk kazał je odprowadzić do gazu. Błagały, bym je uratował. Mówiły do mnie: - dlaczego mamy być zagazowane? Jesteśmy przecież silne i możemy pracować! Przewodniczący: - ile miały wtedy lat? Świadek: - cztery do pięciu. Przewodniczacy: - i co dalej? Świadek: - poszedłem protestować do Kaduka. Zapytałem go, co powie na to Berlin. Kaduk zaśmiał się i rzekł, machajac ręka: - Berlin nic nie powie. W chwile potem, gdy stałem obok baraku, przechodził transport do gazu. Dzieci, widząc mnie, wybiegły z kolumny. Wtedy Kaduk wyciagnał rewolwer i zastrzelił je wszystkie. W miarę relacji głos świadka podniósł się, by wreszcie przejść w krzyk: - Było tak, Kaduk? Mów!! W tym momencie Woerl zerwał się i skoczył ku Kadukowi. Kaduk zerwał się $z$ kolei ku niemu. Twarz miał sino czerwona. $Z$ jego gardła wydobywało się nieartykułowane wycie. Zaciśnięta pięść podniósł w górę. Policjanci podbiegli, by ich rozdzielić. Przewodniczący przywołuje Kaduka do spokoju i pyta: - Oskarżony zastrzelił czy nie? Kaduk: - to kłamstwo! Przecież nie miałem wtedy broni przy sobie. Biedny SS-man. Prowadził ludzi do gazu, będąc bezbronnym... ${ }^{39}$.

Podczas procesu oskarżeni utworzyli zamknięta grupę. Jej funkcjonowanie opierało się na przestrzeganiu ściśle określonych norm, $\mathrm{w}$ wielu wypadkach hołdującym ideologii nazistowskiej. Oskarżeni w dalszym ciagu respektowali hierarchię SS. Na czele grupy staną

38 Problem dotyczacy składania zeznań przez polskich świadków stał się głównym punktem zaczepienia strony zachodnioniemieckiej w oskarżeniach wobec Polski o urabianie świadków przed ich przyjazdem na proces. Dowodem świadczącym na niekorzyść strony polskiej było stanowisko władz polskich, w którym dobitnie stwierdzono, że świadkowie, którzy zostana przez sąd przepytani w tej sprawie, odmówią udziału w procesie. Ł. Polniak, Patriotyzm wojskowy $w$ PRL $w$ latach 1956-1970, Wydawnictwo TRIO, Warszawa 2011, s. 194-195.

39 R. Wojna, „Zwykty” dzień procesu katów, „Trybuna Robotnicza” 1964, nr 82, s. 2. 
dawny aptekarz obozowy - Viktor Capesius, który wśród sądzonych posiadał najwyższy stopień SS - Sturmbannführera (stopień odpowiadający majorowi w pozostałych formacjach wojskowych III Rzeszy) ${ }^{40}$. Obecni na sali sadowej oskarżeni nagminnie przerzucali odpowiedzialność za przestępstwa na nieżyjących już zbrodniarzy (najczęściej swoich dawnych przełożonych). Starano się ponadto składać zeznania w takiej formie, aby nie obarczały one oskarżonych obecnych na sali rozpraw. Jako przykład może posłużyć były obozowy dentysta dr Willy Frank, któremu zarzucano udział w selekcjach na tzw. rampie. Frank wśród oskarżonych nie rozpoznał żadnego byłego esesmana, który w takich selekcjach uczestniczył. Jedynym nazwiskiem które sobie przypomniał był Rudolf Höss - komendant obozu (nieżyjący od 1947 r.):

Czy pamięta może innych współoskarżonych $\mathrm{z}$ okresu działalności w obozie? Zwłaszcza tych na rampie kolejowej, gdzie był przecież, jak sam przyznaje, około 20 razy? Nie. Żadnego tam nie widział. Pamięta jedynie, że był tam Hoess i to nawet wówczas, kiedy już nie był komendantem Oświęcimia ${ }^{41}$.

Jednym $z$ niewielu przypadków złamania zmowy milczenia oskarżonych sa zeznania Stefana Baretzkiego, który skierował oskarżenie względem dra Franza Bernharda Lucasa. Wbrew przyjętej taktyce obrony zarzucił mu m.in. udział w selekcjach na tzw. rampie. Wywód Baretzkiego doprowadził do ostrej wymiany zdań z Lucasem:

Przez 14 miesięcy Baretzki wysłuchiwał zapewnień współoskarżonego Lucasa, iż „ręce ma czyste” i wreszcie teraz przemówił. Oświadczył on mianowicie, iż dr Lucas, tak jak i inni lekarze SS, bywał na rampie kolejowej w Brzezince i przeprowadzał selekcje wśród ludzi przywożonych do obozu, decydując, kto ma iść do komór gazowych, a kto do obozu [...] Usłyszawszy to oskarżony Lucas powiedział, iż to wszystko jest nieprawda, albowiem nie był już wówczas lekarzem obozowym w Brzezince, kiedy likwidowano obóz z Teresina. Na to oskarżony Baretzki zerwał się z miejsca i zawołał: - To nie zgadza się. Lucas był lekarzem obozowym, kiedy likwidowany był obóz ludzi z Teresina. Jeśli dziś mówi on, że pomagał więźniom, to dotyczy to okresu tuż przed klęska, kiedy chciał tą droga zapewnić sobie „bilet powrotny”. Przedtem jednakże kierował tysiace do gazu"! ${ }^{42}$

${ }^{40}$ M. Kieta, Po co ten proces-mamut? mówia obrońcy $w$ procesie oświęcimskim, „Przekrój" 1965, nr 1060, s. 4.

41 Proces oprawców z Oświęcimia. Kaci umywaja ręce, „Trybuna Robotnicza” 1964 , nr 21, s. 2.

${ }^{42}$ Na procesie oświęcimskim. Współoprawcy zaczynaja się „sypać”, „Trybuna Robotnicza" 1965 , nr 42, s. 2. Pełne zeznanie Baretzkiego: zob. 1. Frankfurter Auschwitz-Prozess. "Strafsache gegen Mulka u.a.", 4 Ks 2/63. Landgericht Frankfurt am Main. 137. Verhandlungstag, 18. 2. 1965. Aussage des Angeklagten Baretzki, https://www.auschwitz-prozess. de/zeugenaussagen/Baretzki-Stefan/ [dostęp: 7 lipca 2020]. 
Krok ten kosztował Baretzkiego utratę dotychczasowej pozycji w grupie. Do końca procesu przebywał w swoistej „wewnętrznej” izolacji, jakiej poddali go inni oskarżeni ${ }^{43}$.

Stosunek oskarżonych do rozprawy obrazuje także przebieg wizji lokalnej, jaka przeprowadzono w Oświęcimiu pomiędzy 15 a 17 grudnia 1964 roku. Spośród 22 oskarżonych tylko jeden - dr Franz Bernhard Lucas - wyraził chęć ponownej wizyty w byłym obozie oświęcimskim. Zabiegi propagandowe stosowane przez polskich dziennikarzy opisujacych wizję lokalna w prasie polskiej były jednoznacznie ukierunkowane na ukazanie przełomowości wydarzenia, a zwłaszcza jego istotnej roli $\mathrm{w}$ demaskowaniu kłamstw oskarżonych oraz w podważaniu linii obrony ich adwokatów. Czynności procesowe przeprowadzone w Oświęcimiu rozwiały m.in. wątpliwości dotyczące procesu zabijania zastrzykami fenolu przez Josefa Klehra oraz szczegółów egzekucji przy tzw. ścianie śmierci ${ }^{44}$. Jedyny oskarżony obecny w Oświęcimiu dr Lucas - zachował kamienna twarz, nawet w obliczu skali potwierdzonych zbrodni. W relacji piszącego dla „Przekroju” Mieczysława Kiety moment ten ujęto w następujący sposób:

Oskarżony Lucas, który tylekroć po tej ziemi stapał, patrzy nieruchomymi oczyma. Trzyma ręce w kieszeni. W gromadzie uczestników wizji tylko ja i tylko on wiemy, widzieliśmy, jak rampa wygladała wtedy: przepełniona krzykiem kobiet i dzieci, zatłoczona... okolona ogniem i dymem krematoriów. Od strony dworca kolejowego rozległ się przeciagły gwizd lokomotywy. Lucas drgnął. Przez ułamek sekundy spotkały się nasze oczy. Jego oczy były przeraźliwie puste... ${ }^{45}$.

Aktywnego wsparcia oskarżonym udzielili ich obrońcy, którzy w niemałej liczbie przypadków podejmowali zabiegi zahaczające o publiczna obronę nazizmu i zaprzeczanie jego zbrodniom. Częstym zabiegiem ze strony adwokatów byłych esesmanów stało się podważanie wiarygodności zeznań świadków, insynuując ich zmowę lub działanie w myśl konkretnej ideologii wrogiej nazizmowi (w domyśle: komunistycznej) ${ }^{46}$. Metodę tę nadzwyczaj chętnie stosował dr Hans Latern-

43 M. Kieta, Po co ten proces-mamut?..., s. 4.

44 Sędzia Hotz dyktuje protokolantowi: Z Tuschraumu można dostrzec wnętrze pokoju, w którym szpilowano więźniów... Widać wyraźnie „czarna ścianę”. Wizja w Oświęcimiu obala argumenty obrony, „Trybuna Robotnicza” 1964, nr 298, s. 2.

45 M. Kieta, Brałem udział w wizji lokalnej w Oświęcimiu, „Przekrój” 1965, nr 1030, s. 4.

46 Pojęcie „zmowy” w kontekście procesów zbrodniarzy nazistowskich pojawiło się po raz pierwszy w Statucie Międzynarodowego Trybunału Wojskowego z 8 września 1945 r. Rozumiano je w sposób nieco inny niż w analizowanym powyżej procesie i wykorzystywano na niekorzyść oskarżonych, dowodząc „zmowy” elity nazistowskiej w celu przejęcia władzy w Republice Weimarskiej. Konstrukcja prawna wywodziła się z amerykańskiego systemu praw- 
$\operatorname{ser}^{47}$. O uczestnictwo w zmowie, uzgadnianiu zeznań oraz przynależność do komunistycznych organizacji (za taką uznano ZBoWiD) został przez niego pomówiony polski świadek Erwin Olszówka:

W czasie zeznań Erwina Olszówki do akcji przystępuje ponownie obrońca dr Laternser. Jego pytania zmierzają wyraźnie do zdyskredytowania polskiego świadka i niewiele maja wspólnego $z$ samym meritum procesu. Laternser pyta mianowicie świadka czy czasami $z$ „kimś” nie uzgadniał swoich zeznań, czy „ktoś” nie pokazywał świadkowi planu sali sądowej, dzięki któremu mógł on rozpoznać obecnie oprawców na ławie oskarżonych, czy spotykał się ze świadkiem Hermannem Langbeinem $z$ Wiednia. [...] Pyta czy świadek nie jest członkiem organizacji... komunistycznych, czy nie jest czasami członkiem partii komunistycznej ${ }^{48}$.

Metody obrane przez wspomnianego adwokata zaowocowały ostrym sporem $z$ prokuratorem Friedrichem Kaulem - reprezentantem wymiaru sprawiedliwości NRD na frankfurckim procesie. Laternser wdał się ponadto w kłótnię $z$ przewodniczącym składu sędziowskiego - dr. Hansem Hofmeyerem - któremu usiłował zarzucić stosowanie „podwójnej miary”. Linia obrony została trafnie podsumowana przez jednego ze świadków obrony:

Przypomniał mi się Raportführer Pallitsch i inni SS-mani, którzy ilekroć widzieli więźniów, rozmawiających we dwóch lub trzech, zawsze wietrzyli spisek i sprzysiężenie ${ }^{49}$.

W podobnym, napastliwym tonie utrzymały się również wystapienia innych obrońców, m.in. Rudolfa Aschenauera. Na 175 rozprawie stwierdził otwarcie, iż prywatny oskarżyciel Henry Ormond kieruje się „ślepa nienawiścią i zemstą w stosunku do Capesiusa"50.

Poważnym zarzutem względem obrońców sądzonych zbrodniarzy była przynależność części $z$ nich do struktur hitlerowskiego wymiaru sprawiedliwości w okresie wojennym. Na łamach polskiej prasy pojawiły się obszerne komentarze dotyczące jednego $z$ adwokatów, Hermanna Stoltinga, którego przeszłość w sądownictwie III Rzeszy została ujawniona już w czasie trwania procesu. Stoltinga zdemaskował

nego. Szerzej: zob. C. Saffeerling, Die Strafbarkeit wegen „Conspiracy” in Nürnberg und Imre Bedeutung für die Gegenwart, „Kritische Vierteljahresschrift für Gesetzgebung und Rechtswissenschaft" 2010, t. 93, s. 65-82; Der Prozess gegen die Hauptkriegsverbrechen vor dem Internationalen Militärgerichtshof, t. 1, Sekretariat des Gerichtshof, Nürnberg 1947, s. 30-45.

47 N.S. Aleksiejew, Odpowiedzialność przestępców hitlerowskich..., s. 74.

48 Kat oświęcimski Schlage aresztowany na sali sadowej. Wstrzasajace zeznania świadków z Chorzowa, „Trybuna Robotnicza” 1964, nr 88, s. 2.

49 M. Kieta, Proces trwa. Zeznaja polscy świadkowie, „Przekrój” 1964, nr 997, s. 5

50 Idem, Po co ten proces-mamut?..., s. 4. 
zachodnioniemiecki dziennikarz Kurt Sauer - członek Związku Prześladowanych przez Reżim Narodowosocjalistyczny (VVN), którego sąd frankfurcki zobowiązał do dostarczenia dowodów potwierdzajacych wysunięte przez niego tezy (pod rygorem kary za zniesławienie). Polska prasa przedstawiła w sposób szczególnie dobitny wizytę Sauera w Bydgoszczy - miejscu wojennej działalności Stoltinga. Zebrane tam relacje osób znajacych niemieckiego adwokata $z$ okresu wojny tylko potwierdzały jego wybitnie antypolskie nastawienie (m.in. zarządzał wyroki skazujące dla Polaków bez dowodów winy, denuncjował ich na gestapo, groził aresztem i ubliżał bez wyraźnych powodów). W przekonaniu krajowej prasy antypolska działalność Stoltinga w okresie wojennym w pełni tłumaczyła jego postawę na sali sądowej (negacja zbrodni wojennych) we Frankfurcie ${ }^{51}$.

Przeciwieństwem adwokatów w procesie frankfurckim stali się prokuratorzy oraz sędziowie. W relacjach $z$ procesu wysteppuja oni niemal wyłącznie jako naturalni sojusznicy świadków, demaskatorzy kłamliwych zeznań oskarżonych oraz nieuczciwych metod stosowanych przez ich adwokatów. Dobrym przykładem takiej postawy był profesor Friedrich Kaul. W trakcie procesu zwalczał on argumentację Laternsera dyskredytujaca polskich świadków. Za punkt wyjścia obrał on twierdzenie, iż zabiegi adwokata w skandaliczny sposób ingerują w osobiste życie dawnych więźniów. Wzajemne kontakty świadków, miały jego zdaniem, wynikać wyłącznie $z$ trudnych przeżyć okresu wojennego ${ }^{52}$. W pozytywnym świetle ukazano także przewodniczacego składu sędziowskiego - dra Hansa Hofmeyera. Sposób w jaki przesłuchiwał oskarżonych miał (według ich relacji) w pełni ukazywać ich zakłamanie. Przykładowo indagujac dra Lucasa w sprawie jego udziału w selekcjach więźniów, Hofmeyer ujawnił szereg sprzeczności w zeznaniach sądzonego (np. jeśli Lucasowi zależało na życiu więźniów, to dlaczego unikał udziału w selekcjach, w których mógłby ich ratować?) ${ }^{53}$. Spór dotyczący obiektywizmu prokuratorów wywołało jednakże zaangażowanie w proces jurystów wschodnioniemieckich ${ }^{54}$.

51 B. hitlerowski prokurator broni oprawców z Oświęcimia, „Trybuna Robotnicza” 1964, $\mathrm{nr}$ 7, s. 2; Bydgoszczanie ujawniaja niedwuznaczna przeszłość okupacyjna H. Stoltinga. Hitlerowski polakożerca w adwokackiej todze. „Trybuna Robotnicza” 1964, nr 19, s. 2.

52 M. Kieta, Proces trwa. Zeznają..., s. 5.

53 Proces oprawców oświęcimskich. Lekarze SS-mani wiedzą o zbrodniach ze... słyszenia, „Trybuna Robotnicza” 1964, nr 23, s. 2.

54 Norma stało się podnoszenie w czasie procesu problemów nie związanych zasadniczo $z$ tematem rozpraw, m.in. politycznych rozbieżności pomiędzy NRD a NRF. Przykład: zob. 1 Frankfurter Auschwitz-Prozess. "Strafsache gegen Mulka u.a.", 4 Ks 2/63. Landgericht 
Jednemu $z$ nich, profesorowi Friedrichowi Karlowi Kaulowi imputowano kierowanie się pobudkami politycznymi, gdyż jednocześnie był członkiem SED. Przynależność do tejże partii wykluczyła $z$ rozpraw innego prawnika pochodzącego $z$ NRD - profesora Jürgena Kuczynskiego (był on także członkiem The Royal Society) ${ }^{55}$.

W zakończeniu watku warto poruszyć stosunek zachodnioniemieckiej opinii publicznej do zagadnienia sądzenia załogi obozu oświęcimskiego przez frankfurcki sąd. Problem ten został również poruszony na łamach prasy. Za interesujący przykład może posłużyć tekst Mieczysława Kiety, w którym autor powołuje się na sondę, jaką przeprowadził wśród obywateli NRF działający we Frankfurcie nad Menem Instytut Badania Opinii Publicznej. Badanie odbyło się w sierpniu 1964 roku. Wśród badanych aż 39 proc. respondentów wyraziło się nieprzychylnie na temat procesu (jednakże tylko 25 proc. spośród nich poparło pomysł wstrzymania procesu frankfurckiego). Wiek osób znajdujacych się w tejże grupie oscylował pomiędzy 35 a 54 rokiem życia. Ich swoisty solidaryzm $z$ oskarżonymi mógł więc wynikać $z$ wychowania odebranego w III Rzeszy. W grupie zwolenników procesu znalazły się osoby młode (16-19 lat), wychowane w okresie powojennym. Szersze grono respondentów popierających proces wywodziło się ponadto $z$ kręgów inteligencji ${ }^{56}$. Swoista niechęć społeczeństwa NRF do rozliczeń $z$ nazistowska przeszłością była także zauważalna podczas samych rozpraw przed sądem. Uwidaczniało to się szczególnie w presji wywieranej na świadków mających zeznawać przed sądem. Groźby oraz nacisk psychiczny ze strony środowisk byłych nazistów w kilku przypadkach skutecznie zablokował możliwość obarczenia winami konkretnych sądzonych. Za przykład może posłużyć następujacy cytat dotyczący zeznań obarczajacych Wilhelma Bogera:

Boger na oczach świadka wrzucał gaz do komór gazowych - ludzie krzyczeli umierając. Świadek milczy. Sędzia nie rezygnuje, przeczyta dalej niedawno składane przez świadka zeznania: „Razu pewnego w jednym $z$ bloków Boger odkrył chronione przez matkę bliźniaki. Kiedy jeden $z$ SS-manów odciagnął zrozpaczona matkę, Boger wziął niemowlęta i zmiażdżył ich główki uderze-

Frankfurt am Main. 179. Verhandlungstag, 29.7.1965. Plädoyer des Verteidigers Laternser für Frank, Capesius, Schatz, https://www.auschwitz-prozess.de/zeugenaussagen/RA-Laternser_Plaedoyer_fuer_Frank_Capesius_und_Schatz/[dostęp: 7 lipca 2020].

55 K. Kakol, Zbrodnia nie ukarana..., s. 25. Zob. 1 Frankfurter Auschwitz-Prozess. "Strafsache gegen Mulka u.a.", 4 Ks 2/63. Landgericht Frankfurt am Main. 28. Verhandlungstag, 19. 3. 1964. Anhörung des Sachverständigen Kuczynski, https://www.auschwitz-prozess. de/zeugenaussagen/Kuczynski-Juergen/ [dostęp: 7 lipca 2020].

56 M. Kieta, Zanik pamięci „Przekrój” 1964, nr 1016, s. 6. 
niem o piec". Czy pan tego też nie pamięta? - pyta wśród zastygłej w przerażeniu sali dr Hofmeyer. Świadek milczy. Wyraźnie walczy z sobą i wreszcie cicho ledwie dosłyszalnie mówi: „Tak, to prawda”. Sędzia pyta jeszcze: „Czy świadek obawia się kolegów oskarżonych, tych co sa na wolności?” Świadek wzrusza ramionami, nic nie mówi. W takiej sytuacji po naradzie sąd podejmuje decyzję o rezygnacji z zeznań tego świadka ${ }^{57}$.

Wyrok w sprawie 22 oskarżonych przed frankfurckim sądem przysięgłych zapadł 19 sierpnia 1965 roku. Ogłoszone wyroki wzbudziły wiele kontrowersji społecznych. Tylko części z oskarżonych zasądzono wyroki w pełni odzwierciedlające ich przestępstwa. Kary dożywotniego więzienia otrzymali: Wilhelm Boger, Josef Klehr, Stefan Baretzki, Franz Johann Hofmann, Emil Bednarek i Oswald Kaduk. Trzech oskarżonych uniewinniono (Wilhelm Schatz, Artur Breitwieser i Johann Schoberth), a pozostałych skazano na kary więzienia od 3,5 do 14 lat więzienia ${ }^{58}$.

\section{ZAKOŃCZENIE}

Rozliczanie się NRF $z$ wojennej przeszłości było szeroko komentowane po wojnie na łamach prasy polskiej. To rzecz naturalna zważywszy na ofiary, jakie poniosła Polska zaatakowana i ograbiona przez III Rzeszę. Straty były ogromne nie tylko te materialne, ale przede wszystkim w ludziach. $Z$ drugiej strony władzom komunistycznym Polski Ludowej zależało, aby wina Niemiec, oczywiście tylko tych Zachodnich była cały czas eksponowana, natomiast zbrodnie sowieckie popełniane na Polakach w czasie minionej wojny były przez cały okres PRL starannie ukrywane. Stąd też ton artykułów i wypowiedzi bardzo mocno akcentował patologiczny system rozliczania się $z$ własna przeszłością, wskazując na kariery wielu nazistów już po wojnie. Prezentowano przy tym niechęć społeczeństwa zachodnioniemieckiego do rozliczeń $z$ własna przeszłością. Za taki stan rzeczy odpowiadało przede wszystkim silne zakorzenienie starszej części społeczeństwa $\mathrm{w}$ ideologii narodowosocjalistycznej oraz wstyd przed ujawnianiem patologii i zbrodni okresu III Rzeszy. Jedynie młode pokolenie Niemców przedstawiano w prasie polskiej jako godne podjęcia się denazyfikacji Niemiec Zachodnich oraz świadome celów towarzyszacych takiemu procesowi. Jako czynnik niewatpliwie utrudniajacy wspomniane

57 Proces oprawców oświęcimskich. Brutalna presja na świadków zbrodni, „Trybuna Robotnicza" 1964, nr 69, s. 2.

58 N. Frei, Kariery w półmroku..., s. 226. 
próby rozliczeń niedwuznacznie wskazywano ogromna liczbę polityków i wojskowych obciążonych narodowosocjalistyczna przeszłościa a zajmujaccych eksponowane stanowiska. Obecność w życiu publicznym osób, takich jak Theodor Oberländer i Heinrich Trettner, stanowiła jedynie bodziec do krytyki ze strony prasy polskiej odradzania się wpływów neonazistowskich w NRF. Wszelkie nieścisłości oraz wewnętrzne skandale natury politycznej i sądowej w Niemczech Zachodnich umiejętnie wykorzystały polskie gazety i czasopisma, kreśląc wizerunek NRF jako państwa, w którym narodowy socjalizm wciąż posiadał moc torpedowania wszelkich działań rozliczeniowych. Wyrazem wpływów apologetów Adolfa Hitlera stała się m.in. działalność organizacji Cicha Pomoc dla Jeńców Wojennych i Internowanych, będąca w rzeczywistości zawoalowanym stowarzyszeniem wspierającym byłych członków $\mathrm{SS}^{59}$.

59 Organizacja działała w NRF od roku 1946 r. (oficjalnie została zarejestrowana w 1951 r.). W gronie jej założycieli znajdowali się byli wyżsi oficerowie SS (m.in. Wilhelm Spengler i Heinrich Malz) oraz hierarchowie Kościoła katolickiego (m.in. biskup pomocniczy Monachium Johannes Heuhäusler). Pierwsza przewodnicząca stowarzyszenia została Helene Elisabeth von Isenburg. O. Schröm, A. Röpke, Cicha Pomoc dla nazistów. Tajna działalność byłych SS-manów i neonazistów, tłum. A.M. Władyka, Wydawnictwo Replika, Zakrzewo 2015, s. 52-53. 